\title{
Two Years Federal Act on the International Transfer of Cultural Property in Switzerland (Bern, Switzerland, May 31, 2007)
}

\section{Kurt Siehr*}

On June 1, 2005, the Swiss Cultural Property Transfer Act (CPTA) of 2003 entered into force. ${ }^{1}$ This statute implements for Switzerland the 1970 UNESCO Convention on the Means of Prohibiting and Preventing the Illicit Import, Export and Transfer of Ownership of Cultural Property. ${ }^{2}$ According to article 7 of the CPTAalong the line followed by the United States in their implementation statute ${ }^{3}$ bilateral agreements must be stipulated with contracting states of the convention so these states will be protected in Switzerland with respect to the items mentioned in these agreements. Yves Fischer and Benno Widmer of the Federal Office for Culture explained the CPTA and the Ordinance on Cultural Property Transfer (CPTO) and mentioned that with Peru and Greece agreements have already been achieved and that agreements with Italy, Egypt, and Mexico are in preparation. Marc-André Renold, director of the Geneva-based Institute of Art and Law, presided the session when question were put to the Federal Office at the end of the conference.

\section{ENDNOTES}

1. English translation in International Journal of Cultural Property, 12 (2005): 467.

2. 823 United Nations Treaty Series 231.

3. 19 U.S.C. $\$ \$ 2601$ et seq.; 19 C.F.R. $\$ 12.104$ g.

\footnotetext{
*University of Zurich Faculty of Law, Max-Planck-Institute, Hamburg. Email: siehr@mpipriv.de
} 